\title{
Effect of litter type and perches on footpad dermatitis and hock burn in broilers housed at different stocking densities
}

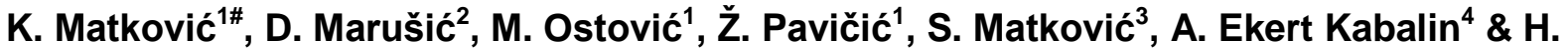

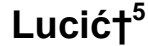 \\ ${ }^{1}$ Department of Animal Hygiene, Behaviour and Welfare, Faculty of Veterinary Medicine, University of Zagreb, \\ Heinzelova 55, 10000 Zagreb, Croatia \\ ${ }^{2}$ Brod-Posavina County, County Prefect Office, UI. Petra Krešimira IV 1, 35000 Slavonski Brod, Croatia \\ ${ }^{3}$ Paying Agency for Agriculture, Fisheries and Rural Development, Ul. grada Vukovara 269d, 10000 Zagreb, Croatia \\ ${ }^{4}$ Department of Animal Breeding and Livestock Production, Faculty of Veterinary Medicine, University of Zagreb, \\ Heinzelova 55, 10000 Zagreb, Croatia \\ ${ }^{5}$ Department of Anatomy, Histology and Embryology, Faculty of Veterinary Medicine, University of Zagreb, \\ Heinzelova 55, 10000 Zagreb, Croatia
}

(Received 12 February 2019; Accepted 22 April 2019; First published online 19 June 2019)

\author{
Copyright resides with the authors in terms of the Creative Commons Attribution 4.0 South African License. \\ See: http://creativecommons.org/licenses/by/4.0/za \\ Condition of use: The user may copy, distribute, transmit and adapt the work, but must recognize the authors and \\ the South African Journal of Animal Science.
}

\begin{abstract}
The aim of the study was to assess the effect of litter type and environmental enrichment on the occurrence of footpad dermatitis and hock burns in broilers housed at low and high stocking densities. Chopped straw and sand were used as litter, and perches as environmental enrichment. Low and high stocking density implied 12 chickens $/ \mathrm{m}^{2}$ and 20 chickens $/ \mathrm{m}^{2}$, respectively. The study sample was divided into four groups of 50 birds, which were observed during a six-week fattening period. A significantly higher rate of severe footpad dermatitis was recorded in the group of chickens raised on sand at high stocking density, compared with low stocking density, whereas no significant difference was found between the groups of chickens raised on straw at different stocking densities. The rate of footpad dermatitis was also significantly higher in the group of chickens raised on sand at high stocking density, compared with chickens raised on straw at the same stocking density. There were no group differences in the occurrences of hock burns and perching. However, a significant negative correlation was recorded between perching and the occurrence of footpad dermatitis and hock burns. According to the occurrence of footpad dermatitis and hock burns, the study results suggested that chopped straw and sand were equally acceptable as litter for broilers, yet sand should be avoided at high stocking densities. There was no effect of stocking density and litter type on perching, but perches as a form of environmental enrichment proved efficient in reducing the rate of footpad dermatitis and hock burns.
\end{abstract}

Keywords: chickens, contact dermatitis, environmental enrichment, housing, sand

\# Corresponding author: kmatkov@vef.hr

\section{Introduction}

Broiler welfare is defined primarily by the genetics, which determines body mass and bone system abnormalities and mobility, all this in synergy with the environment. The genetically determined fast growth of broilers results in their decreased activity and prolonged time they spend sitting. This, in combination with poor litter quality, favours the development of leg disorders such as footpad dermatitis (FPD) and hock burns (HB) (Bessei, 2006; Shepherd \& Fairchild, 2010).

Footpad dermatitis and HB are a type of contact dermatitis, which also refers to breast blisters, which is characterized by hyperkeratosis and epidermal necrosis, and even tissue ulceration with subcutaneous inflammatory reaction in the most severe cases (Greene et al., 1985; Swiatkiewicz et al., 2017). The condition can be worsened by secondary infections (Berg, 2004). Leg lesions become increasingly painful with the progression of the inflammation. Broilers cannot walk, feed and drink normally anymore, and spend more time sitting and resting, failing to thrive. The inability to walk and to express other important behaviours 
causes frustration in broilers, even leading to starving in the worst cases (Bradshaw et al., 2002). Many studies of broiler welfare point to contact dermatitis as the key indicator, that is, the main problem for their welfare (ICFAW, 2009; De Jong et al., 2014). Shepherd \& Fairchild (2010) emphasized the role of prevention of contact dermatitis, not only from the standpoint of broiler welfare, but also for food safety and economic cost-effectiveness. Nowadays, there is growing demand for chicken legs on the market worldwide, as the third most important part of the chicken economically, following only chicken breasts and wings.

Contact dermatitis is caused primarily by moisture and irritating chemical substances in the litter (Bessei, 2006; Taira et al., 2014). The activity of microorganisms is intensified in wet litter, which results in temperature increase and ammonia production (Matković et al., 2015). The level of litter moisture depends on a number of factors, including litter type and amount, type of drinking and ventilation system, microclimate conditions, season, chicken age, nutrition and health (enteritis), and stocking density (Bessei, 2006; Shepherd \& Fairchild, 2010; Dunlop et al., 2016). A higher incidence of FPD and HB in broilers was recorded at higher stocking density (Buijs et al., 2009; Farhadi et al., 2016), which can be explained by increased litter moisture because at high stocking density, broilers take more water and produce more faeces, along with poorer heat transfer from litter surface to the ventilated space (Bessei, 2006; Shepherd \& Fairchild, 2010). In addition, high stocking densities may cause lesions directly to broiler skin, as they have to push through and climb over one another in search for feed, water, and a place to rest (De Jong et al., 2012), which can favour FPD and HB development. Furthermore, at high stocking densities, broiler movement is restricted and they spend most of the time sitting (Ventura et al., 2012), thus making litter type ever more important to prevent FPD and HB.

Previous studies reported on sand as an acceptable alternative to other litter materials in broilers. In comparison with pine shavings, sand was found to have lower water activity, moisture content and bacterial counts (Macklin et al., 2005). Chickens raised on sand also showed a lower incidence of FPD (Bilgili et al., 2009) and HB (Simsek et al., 2009). Studies that compared sand and straw as litter materials - straw being most widely used as a litter type in fattening broilers in Europe (Shepherd \& Fairchild, 2010) - also pointed to the advantages of sand as a litter material, including lower moisture (Ramadan et al., 2013) and FPD score (Bilgili et al., 2009). However, to the authors' knowledge, no studies have investigated the effect of stocking density on FPD and HB in broilers raised on sand or on sand with the addition of perches as environmental enrichment, which has been demonstrated to reduce the incidence of FPD (Hongchao et al., 2014) and HB (Simsek et al., 2009). In addition, stocking density has been reported to influence perching in broilers (PettitRiley \& Estevez, 2001; Ventura et al., 2012).

The aim of the present study was to assess the occurrence of FPD and HB in broilers raised on straw and on sand at different stocking densities, with the environment being enriched with perches.

\section{Materials and Methods}

The study was conducted in a closed broiler house at a family farm during a six-week fattening period in spring. Broilers were divided into four groups, each group being housed in a separate space that was separated with wire netting. Two groups of broilers were raised on chopped straw, and another two on sand, at different stocking densities. Low stocking density implied 12 birds $/ \mathrm{m}^{2}$ and high stocking density implied 20 birds $/ \mathrm{m}^{2}$. Thus, 50 Ross 308 hybrid broilers were housed in each space, with the usable area of two spaces being $4.2 \mathrm{~m}^{2}$ and of the other two spaces being $2.5 \mathrm{~m}^{2}$. The litter (straw and sand) depth was $5 \mathrm{~cm}$ in all groups and it was not turned over, nor was new litter added throughout the fattening period. Sand was dried before use. In each group of broilers, the space was enriched with two wooden perches, $160 \mathrm{~cm}$ long $\times 2.5$ $\mathrm{cm}$ wide $\times 2.5 \mathrm{~cm}$ deep, which were placed between the feeders and drinkers from halfway through the first week to the end of the third week of fattening at the height of $5 \mathrm{~cm}$, and then at $10 \mathrm{~cm}$.

The broilers were kept in technologically determined microclimate conditions, with mechanical ventilation and Heatmaster (Big Dutchman International $\mathrm{GmbH}$, Vechta, Germany) heating. They were fed with commercial feed from bell feeders and water from nipple drinkers, with ad libitum feeding and drinking. The lighting cycle was set in accordance with recommendations for Ross broilers (Anonymous, 2014a).

Microclimate conditions and litter moisture were measured once weekly during the fattening period (on days 1, 8, 15, 22, 29 and 39). Litter samples were obtained from the second week. Air temperature, relative humidity and airflow velocity, and air concentrations of ammonia and carbon dioxide were measured with portable digital devices (Testo SE \& Co. KGaA, Lenzkirch, Germany, and Dräger Safety AG \& Co. KGaA, Lübeck, Germany) at three sites in each group of broilers, in their biozone. Litter moisture was determined in a pooled litter sample, with the litter being sampled at three sites, that is, under the drinker, in the corner, and in the centre of each space. The samples were transported to the laboratory and analysed on the same day. Litter samples were weighed before and after drying at a temperature of $105^{\circ} \mathrm{C}$ until constant weight. The percentage of litter moisture was calculated with the formula: 


\section{$\%$ of litter moisture $=$ weight of wet litter - weight of dry litter $x$ 100/weight of wet litter}

Broiler perching was assessed weekly by counting broilers on perches for 240 minutes of observation (8:00 - 10:00 and 13:00 - 15:00) at two-minute intervals, as reported elsewhere (Ramadan et al., 2013; Ostović et al., 2015), always by the same observer. The results were expressed as the mean number of perching broilers per group during the fattening period. Perching implied that the broilers were standing or sitting on perches.

The occurrence of FPD and HB was assessed according to the official instructions of Croatian Veterinary and Food Safety Directorate on post-mortem inspection and result evaluation to identify the possible signs of poor housing conditions at a farm considering welfare of chickens raised for meat production (Anonymous, 2014b).

The use of official instructions was also proposed by De Jong et al. (2016). Twenty (40\%) randomly selected broilers from each group as a representative sample were examined once a week, starting from the second week. The same bird was examined for the occurrence of FPD and HB.

Footpad dermatitis was scored as follows:

0 : Legs free of lesions/changes or with a small area affected including slight colour change in a limited footpad area, superficial lesion of up to $5 \mathrm{~mm}$ in size and/or a scar

1: Legs with mild lesions/changes not spreading across the whole footpad, including considerable colour change in a limited footpad area, major superficial lesion without ulceration and/or affected areas of dark/black colour but without ulceration

2: Legs with extensive lesions/changes spreading all over the footpad, occasionally even involving toes. These lesions/changes include deep tissue lesions with ulceration (occasionally also haemorrhage), big crusts and/or severe footpad oedema

Hock burns were scored as follows:

0 : Joints free from lesions/changes or with a small area of the tarsal joint of up to $5 \mathrm{~cm}$ in size being affected, including slight colour change in a limited joint area and/or superficial lesion

1: Presence of lesions/changes including colour change in a joint area of $>5 \mathrm{~mm}$ in circumference, superficial lesion greater than $5 \mathrm{~mm}$ and/or dark-brown or black areas in the posterior aspect of the joint

When the broiler legs were scored differently, the higher FPD and HB scores were considered. The results on FPD and HB occurrence were expressed as the mean number of broilers with lesions per group during fattening, with the recorded values of FPD severity also reported per week.

During the study period, one broiler per group died in the groups housed at high stocking density.

Tibco Statistica version 13.4 (Tibco Software Inc., 2017) software was used for statistical data analysis. Data were processed by standard procedures of descriptive statistics, with the normality of distribution tested by Kolmogorov-Smirnov test. Differences between the groups were assessed by one-way analysis of variance or Kruskal-Wallis ANOVA, depending on the type and distribution of variables, whereas within-group differences (between weeks) were tested by repeated measures ANOVA or Friedman ANOVA. Correlation between the study variables was assessed by coefficient of linear correlation or Spearman rank order correlation. The level of statistical significance was set at $P<0.05$.

The study trials were approved by the Ethics Committee of the Faculty of Veterinary Medicine, University of Zagreb.

\section{Results and Discussion}

The measured values of microclimate indicators were comparable in all broiler groups, which was expected because they were kept in the same house. During the fattening period, the air temperature ranged from $21.2{ }^{\circ} \mathrm{C}$ to $30{ }^{\circ} \mathrm{C}$, relative humidity from $49.6 \%$ to $65.5 \%$, airflow velocity from $0.01 \mathrm{~m} / \mathrm{s}$ to $0.5 \mathrm{~m} / \mathrm{s}$, and ammonia and carbon dioxide concentrations from $3.25 \mathrm{ppm}$ to $26.9 \mathrm{ppm}$ and 0.08 vol.\% to 0.33 vol.\%, respectively. The microclimate conditions in the house were in line with the values recorded in other studies (Vučemilo et al., 2007; 2008).

Taira et al. (2014) reported that FPD started to occur in broilers in the second week of the fattening period. This was related to litter moisture, which is consistent with the study by Avdalovic et al. (2017), in which the initial signs of FPD were observed in the third week. Kjaer et al. (2006) noticed the initial signs of FPD and HB in the second week. Meluzzi et al. (2008) and De Jong et al. (2014) also found higher litter moisture content to be associated with a higher occurrence of FPD and HB. Similar findings were reported by Bilgili et al. (2009), who compared various types of litter, including straw and sand, and found the rate of FPD to be lowest in broilers that were raised on sand with the lowest moisture content.

In the current study, the first signs of FPD and HB were observed at the beginning of the third week in all groups. Throughout the fattening period, litter moisture was higher in the groups of broilers raised on straw as opposed to sand, irrespective of stocking density (Figure 1), but there was no correlation $(P>0.05)$ 
between litter moisture and the occurrence of FPD and HB (Table 1). Nagaraj et al. (2007) and Ramadan et al. (2013) found that litter moisture had no effect on the occurrences of FPD and HB in broilers. However, other studies revealed that factors such as litter texture, season, lighting cycle, genotype and stocking density influenced the occurrence of contact dermatitis in broilers (Buijs et al., 2009; Shepherd \& Fairchild, 2010; Škrbić et al., 2015; Farhadi et al., 2016; Avdalovic et al., 2017).

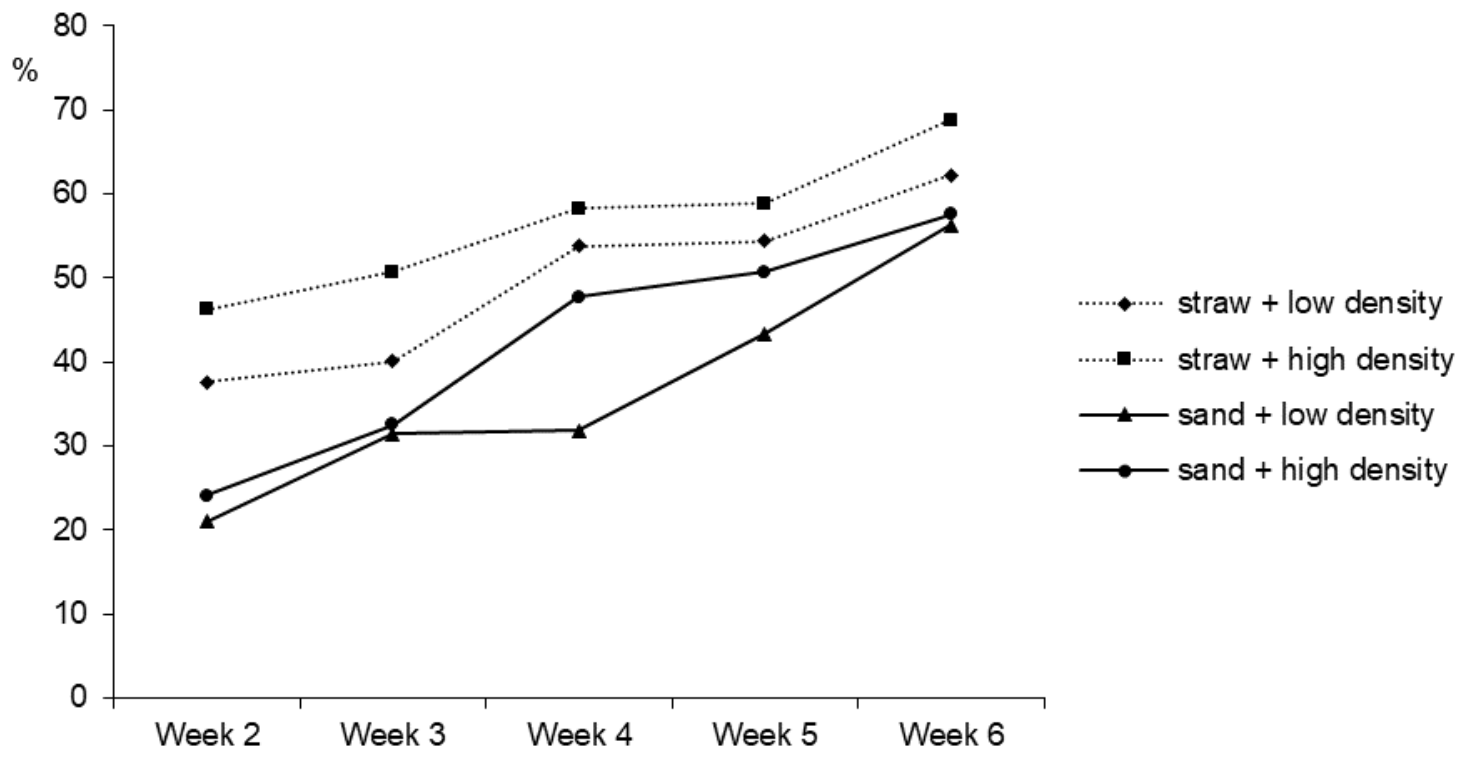

Figure 1 Straw and sand moisture (\%) in broiler groups raised at low and high stocking densities during sixweek fattening period*

Table 1 Correlation of litter moisture and perching with the occurrence of footpad dermatitis and hock burns in broilers

\begin{tabular}{lccccc}
\hline & $\begin{array}{c}\text { Broilers with } \\
\text { FPD (n) }\end{array}$ & $\begin{array}{c}\text { FPD } \\
\text { severity }\end{array}$ & $\begin{array}{c}\text { Broilers with } \\
\text { HB (n) }\end{array}$ & $\begin{array}{c}\text { Litter } \\
\text { moisture (\%) }\end{array}$ & $\begin{array}{c}\text { Perching } \\
\text { broilers (n) }\end{array}$ \\
\hline Broilers with FPD (n) & \multirow{2}{*}{1.00} & $0.94^{*}$ & $0.61^{*}$ & 0.12 & $-0.54^{*}$ \\
FPD severity & & 1.00 & $0.57^{*}$ & -0.04 & $-0.53^{*}$ \\
Broilers with HB (n) & & & 1.00 & 0.12 & $-0.41^{*}$ \\
Litter moisture (\%) & & & & 1.00 & $-0.40^{*}$ \\
Perching broilers (n) & & & & & 1.00 \\
\hline
\end{tabular}

${ }^{*} P<0.05 ;$ FPD - footpad dermatitis; HB - hock burns

The mean frequency of FPD was highest in broilers that were raised on sand at high stocking density, which differed $(P<0.01)$ from the frequency recorded in broilers raised on sand at low density, and those raised on straw at high density (Figure 2). In addition, FPD in broilers raised on sand at high density was on average more severe $(P<0.01)$ than that of broilers raised on sand at low density (Figure 3 ). These results could be explained by the higher release of ammonia in sand as opposed to straw, owing to lower litter caking (Tasistro et al., 2007) as an important factor in the aetiology of contact dermatitis (Bessei, 2006), which was more pronounced at higher stocking density. Bilgili et al. (2009) found sand was characterized by lower moisture and caking compared with straw, without differences in the release of ammonia between litter materials, whereas the occurrence of FPD was lower in broilers raised on sand. However, stocking density was lower in their study. Other studies also revealed that high litter moisture suppressed the release of ammonia (Liu et al., 2007). 
In the current study, there were no differences $(P>0.05)$ in the mean frequency and severity of FPD between the groups of broilers raised on straw at low and high stocking densities (Figures 2 and 3 ), suggesting that litter type and litter management should be taken in consideration when assessing the effect of stocking density on the occurrence of contact dermatitis. In the present study, neither sand nor straw was turned over, nor was new material added throughout the fattening period. Numerous studies have reported contradictory conclusions on the effect of stocking density on the occurrence of contact dermatitis in broilers. However, results can vary depending on whether the study was conducted in experimental conditions or in real husbandry conditions that are characterized by a greater number of animals and specific production situations (De Jong et al., 2012).

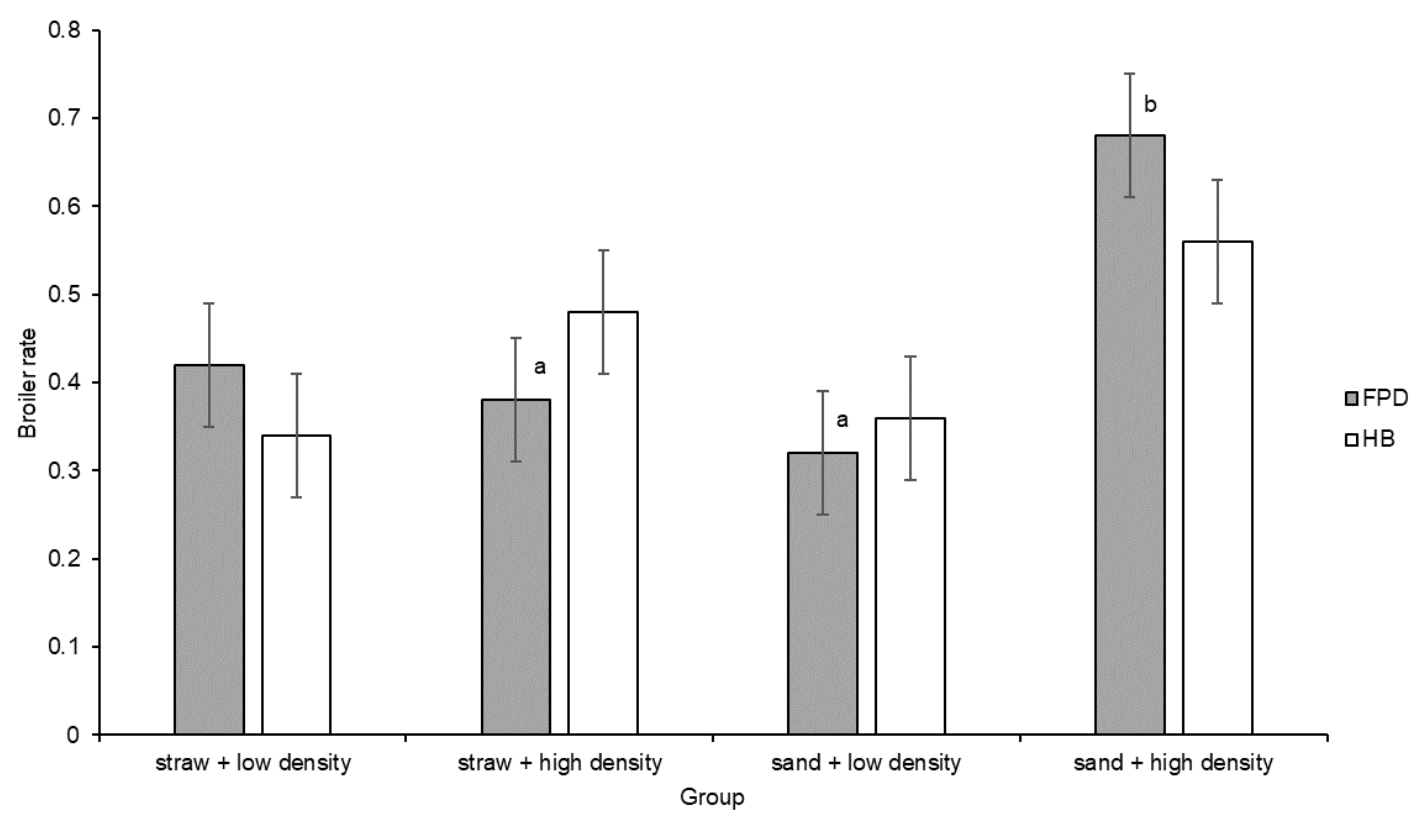

Figure 2 Mean rate ( \pm SEM) of broilers with footpad dermatitis and hock burns, according to groups raised on straw and sand at low and high stocking densities during six-week fattening period $\mathrm{n}=20$ birds per group

${ }^{a, b}$ Values with different superscripts differ significantly at $P<0.01$

A comparison of FPD severity in particular broiler groups according to weeks - except for the second week in which no changes were observed - yielded differences only in broilers that were raised on straw at high stocking density. Higher FPD severity $(P<0.05)$ was found in the last week of the fattening period. When the second week was taken into account, differences were at the level of $P<0.05$ in all broiler groups compared with the last week, except for the group of broilers that were raised on sand at low stocking density, in which there were no differences $(P>0.05)$ between fattening weeks. In the group of broilers that were raised on sand at high stocking density, higher FPD severity $(P<0.05)$ was recorded in all weeks in comparison with the second week (Table 2). Accordingly, in other groups of broilers, FPD severity increased with fattening weeks, whereas in broilers raised on sand at high stocking density changes in footpad area were extensive as soon as they appeared and followed this trend until the end of the fattening period.

In terms of the degree of severity of FPD among groups according to weeks, in the third week higher values $(P<0.05)$ were recorded in broilers raised on sand at high stocking density, compared with broilers raised on sand at low stocking density and on straw at high stocking density (Table 2). Just after the second week, broilers started to spend an increasing amount of time sitting (Bessei, 2006), which was more pronounced on sand than on straw (Ramadan et al., 2013) and at higher stocking density (Ventura et al., 2012). This could have produced these results. In the fourth week, higher severity of FPD $(P<0.05)$ was recorded in broilers that were raised on sand, compared with straw, at high stocking density, whereas no between-group differences $(P>0.05)$ were found in the fifth and sixth weeks, except for the sixth week between broilers raised on straw at high stocking density and those raised on sand at low stocking density $(P$ $<0.05$ ) (Table 2). 


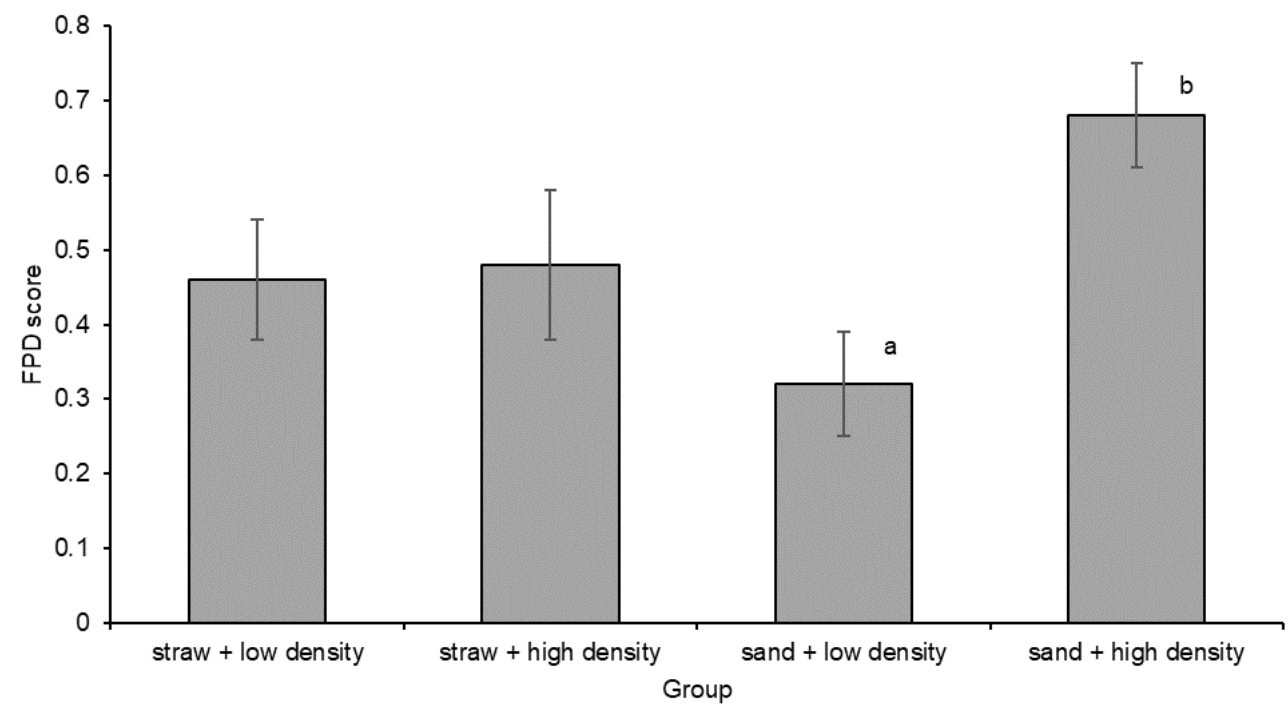

Figure 3 Mean footpad dermatitis (FPD) severity ( \pm SEM) in broilers according to groups raised on straw and sand at low and high stocking densities during six-week fattening period $\mathrm{n}=20$ birds per group

a,b Values with different superscripts differ significantly at $P<0.01$

Table 2 Severity of footpad dermatitis in broilers raised on straw and sand at low and high stocking densities during six-week fattening period*

\begin{tabular}{|c|c|c|c|c|c|c|}
\hline Group & & Week 2 & Week 3 & Week 4 & Week 5 & Week 6 \\
\hline Straw + low density & & $0^{\mathrm{a}}$ & $0.40 \pm 0.16$ & $0.40 \pm 0.16$ & $0.60^{b} \pm 0.16$ & $0.90^{\mathrm{b}} \pm 0.23$ \\
\hline Straw + high density & FPD & $0^{\mathrm{a}}$ & $0.20^{\mathrm{a}, \mathrm{A}} \pm 0.13$ & $0.20^{\mathrm{a}, \mathrm{A}} \pm 0.13$ & $0.50^{\mathrm{a}} \pm 0.17$ & $1.50^{\mathrm{b}, \mathrm{A}} \pm 0.17$ \\
\hline Sand + low density & $\begin{array}{l}\text { Mean } \\
\pm \text { SEM }\end{array}$ & 0 & $0.20^{A} \pm 0.13$ & $0.40 \pm 0.16$ & $0.50 \pm 0.17$ & $0.50^{B} \pm 0.17$ \\
\hline Sand + high density & & $0^{\mathrm{a}}$ & $0.80^{\mathrm{b}, \mathrm{B}} \pm 0.13$ & $0.80^{\mathrm{b}, \mathrm{B}} \pm 0.13$ & $0.80^{b} \pm 0.13$ & $1.00^{\mathrm{b}} \pm 0.00$ \\
\hline
\end{tabular}

*No measurement in first week

$\mathrm{n}=20$ birds per group

${ }_{a, b}$ Values in the same row with different superscripts differ significantly at $P<0.05$

${ }_{A}^{A} \mathrm{~B}$ Values in the same column with different superscripts differ significantly at $P<0.05$

FPD - footpad dermatitis

A positive correlation was observed between the occurrences of FPD and HB $(P<0.05)$ (see also Meluzzi et al., 2008 and De Jong et al., 2014). However, the current groups did not differ $(P>0.05)$ in the mean occurrence of HB (Figure 2), which could be because hock lesions develop more slowly and are less common than footpad lesions (EC, 2000). Other studies found no effect of litter type and quality (Haslam et al., 2006; Terčič et al., 2015) or stocking density (Haslam et al., 2007) on the occurrence of HB in broilers.

The barren environment in intensive broiler production offers minimal stimulation and limited movement. It has thus proved useful to enrich it. In the present study, all broiler groups were provided with wooden perches. Studies have demonstrated that climbing up and down perches and sitting on them stimulates the musculoskeletal system to movements that are different from those used in standing and walking, thus strengthening broiler legs (Bizeray et al., 2002). Broilers are motivated to perch, but use perches rarely after the age of four weeks (Pettit-Riley \& Estevez, 2001; Ventura et al., 2012). Their increased breast muscles have shifted the centre of gravity forward, which makes jumping and balance on perches difficult (Kaukonen et al., 2017). In the present study, broilers in all study groups perched rarely from the third week onwards. Overall, during fattening, perches were used by less than $10 \%$ of broilers in each group (Figure 4). 


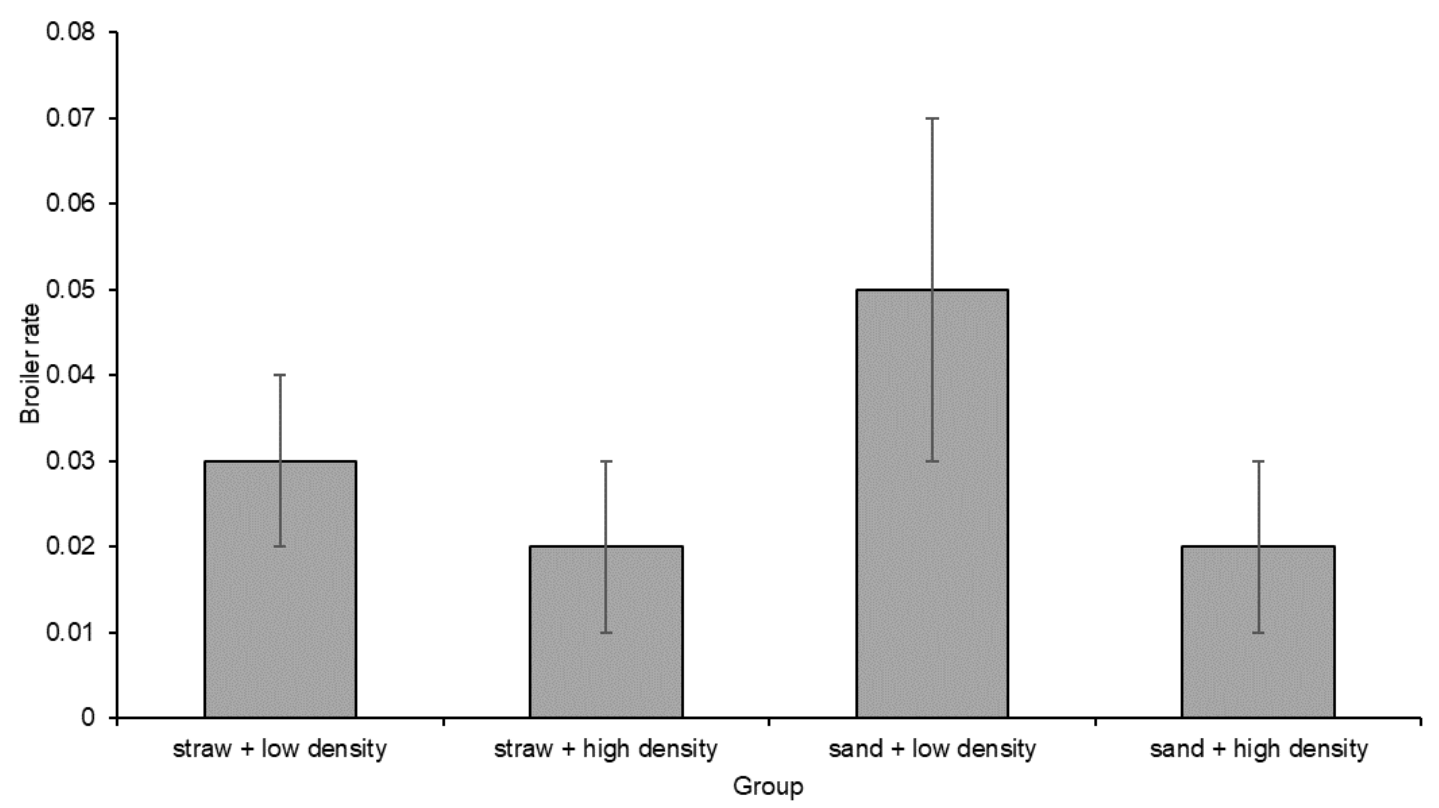

Figure 4 Mean rate $( \pm$ SEM) of perching broilers according to groups raised on straw and sand at low and high stocking densities during six-week fattening period $\mathrm{n}=50$ birds per group

Pettit-Riley \& Estevez (2001) found that broilers that were raised at higher stocking density used perches more frequently, whereas Ventura et al. (2012) reported the opposite. In this study, there were no differences $(P>0.05)$ between broiler groups according to perching, based on four-hour observations. Yet the authors found a negative correlation $(P<0.05)$ between perching and the occurrence of FPD and HB (Table 1). Other authors reported that the higher rate of perching was associated with a lower occurrence of FPD (Hongchao et al., 2014) and HB (Simsek et al., 2009).

Various objects could enrich the environment for broilers. However, additional studies in practice are needed to define their effects and practical application in more detail (Riber et al., 2018). The current study is one of few that were carried out in real commercial production conditions on a farm.

The results can serve as recommendations for production conditions, although additional studies are suggested to investigate the mutual effects of various types of litter (Avdalovic et al., 2017; Kheravii et al., 2017), stocking densities and environmental enrichment (platforms, ramps, and outdoor access (ICFAW, 2009; Zhao et al., 2014; Norring et al., 2016; Kaukonen et al., 2017) on the occurrence of contact dermatitis and other health, behavioural and production indicators in broilers.

\section{Conclusion}

The results of the current study suggest that in terms of the occurrences of FPD and HB, sand as a litter material for broilers is a good alternative to chopped straw at low stocking density. In addition, the use of perches as environmental enrichment appears to help reduce the occurrences of FPD and HB in broilers, irrespective of stocking density and type of litter.

\section{Authors' Contributions}

Drafting, data collection, writing, editing: $\mathrm{KM}$; data collection and writing: $\mathrm{DM}, \mathrm{HL}$; writing, reviewing and editing: MO; data collection and drafting: ŽP, SM; data analysis: AEK. All authors read and approved the final manuscript.

\section{Conflict of Interest Declaration}

The authors declare that there is no potential conflict of interest.

\section{References}

Anonymous, 2014a. Ross Broiler Management Handbook. Available at http://en.aviagen.com/assets/Tech_Center/Ross_Broiler/Ross-Broiler-Handbook-2014i-EN.pdf. Accessed 9 January 2019.

Anonymous, 2014b. Croatian Veterinary and Food Safety Directorate Official Instructions on Post-mortem Inspection and Result Evaluation to Identify the Possible Signs of Poor Housing Conditions at a Farm Considering Welfare of Chickens Raised for Meat Production. Ministry of Agriculture, Zagreb, Croatia. (in Croatian) 
Avdalovic, V., Vucinic, M., Resanovic, R., Avdalovic, J., Maslic-Strizak, D. \& Vucicevic, M., 2017. Effect of pelleted and chopped wheat straw on footpad dermatitis in broilers. Pak. J. Zool. 49, 1639-1646.

Berg, C., 2004. Pododermatitis and hock burn in broiler chickens. In: C.A. Weeks \& A. Butterworth (eds). Measuring and Auditing Broiler Welfare. CABI, Wallingford, UK. pp. 37-49.

Bessei, W., 2006. Welfare of broilers: A review. Worlds Poult. Sci. J. 62, 455-466.

Bilgili, S.F., Hess, J.B., Blake, J.P., Macklin, K.S., Saenmahayak, B. \& Sibley, J.L., 2009. Influence of bedding material on footpad dermatitis in broiler chickens. J. Appl. Poult. Res. 18, 583-589.

Bizeray, D., Estevez, I., Leterrier, C. \& Faure, J.M., 2002. Influence of increased environmental complexity on leg condition, performance and level of fearfulness in broilers. Poult. Sci. 81, 767-773.

Bradshaw, R.H., Kirkden, R.D. \& Broom, D.M., 2002. A review of the aetiology and pathology of leg weakness in broilers in relation to welfare. Avian Poult. Biol. Rev. 13, 45-103.

Buijs, S., Keeling, L., Rettenbacher, S., Van Poucke, E. \& Tuyttens, F.A.M., 2009. Stocking density effects on broiler welfare: Identifying sensitive ranges for different indicators. Poult. Sci. 88, 1536-1543.

De Jong, I., Berg, C., Butterworth, A. \& Estevez, I., 2012. Scientific report updating the EFSA opinions on the welfare of broilers and broiler breeders. Supporting Publications 2012:EN-295. Available at http://www.efsa.europa.eu/en/supporting/pub/en-295. Accessed 20 December 2018.

De Jong, I.C., Gunnink, H. \& Van Harn, J., 2014. Wet litter not only induces footpad dermatitis but also reduces overal welfare, technical performance, and carcass yield in broiler chickens. J. Appl. Poult. Res. 23, 51-58.

De Jong, I.C., Hindle, V.A., Butterworth, A., Engel, B., Ferrari, P., ..., Van Reenen, C.G., 2016. Simplifying the Welfare Quality ${ }^{\circledR}$ assessment protocol for broiler chicken welfare. Animal 10, 117-127.

Dunlop, M.W., Moss, A.F., Groves, P.J., Wilkinson, S.J., Stuetz, R.M. \& Selle, P.H., 2016. The multidimensional causal factors of 'wet litter' in chicken-meat production. Sci. Total Environ. 562, 766-776.

European Commission (EC), 2000. The welfare of chickens kept for meat production (broilers). Report of the Scientific Committee on Animal Health and Animal Welfare. Available at https://ec.europa.eu/food/sites/food/files/safety/docs/sci-com_scah_out39_en.pdf. Accessed 11 December 2018.

Farhadi, D., Hosseini, S.M. \& Dezfuli, B.T., 2016. Effect of house type on growth performance, litter quality and incidence of foot lesions in broiler chickens reared in varying stocking density. J. BioSci. Biotechnol. 5, 69-78.

Greene, J.A., McCracken, R.M. \& Evans, R.T., 1985. A contact dermatitis of broilers - clinical and pathological findings. Avian Pathol. 14, 23-38.

Haslam, S.M., Brown, S.N., Wilkins, L.J., Kestin, S.C., Warriss, P.D. \& Nicol, C.J., 2006. Preliminary study to examine the utility of using foot burn or hock burn to assess aspects of housing conditions for broiler chicken. Br. Poult. Sci. 47, 13-18.

Haslam, S.M., Knowles, T.G., Brown, S.N., Wilkins, L.J., Kestin, S.C., Warriss, P.D. \& Nicol, C.J., 2007. Factors affecting the prevalence of foot pad dermatitis, hock burn and breast burn in broiler chicken. Br. Poult. Sci. 48, 264-275.

Hongchao, J., Jiang, Y., Song, Z., Zhao, J., Wang, X. \& Lin, H., 2014. Effect of perch type and stocking density on the behaviour and growth of broilers. Anim. Prod. Sci. 54, 930-941.

International Coalition For Animal Welfare (ICFAW), 2009. OIE guidelines for the on-farm welfare of chickens raised for meat. Available at: http://www.icfaw.org/Documents/ICFAW-OIE guidelines for the on-farm welfare of chickens raised for meat.pdf. Accessed 10 January 2019.

Kaukonen, E., Norring, M. \& Valros, A., 2017. Perches and elevated platforms in commercial broiler farms: Use and effect on walking ability, incidence of tibial dyschondroplasia and bone mineral content. Animal 11, 864-871.

Kheravii, S.K., Swick, R.A., Choct, M. \& Wu, S.B., 2017. Potential of pelleted wheat straw as an alternative bedding material for broilers. Poult. Sci. 96, 1641-1647.

Kjaer, J.B., Su, G., Nielsen, B.L. \& Sørensen, P., 2006. Footpad dermatitis and hock burn in broiler chickens and degree of inheritance. Poult. Sci. 85, 1342-1348.

Liu, Z., Wang, L., Beasley, D. \& Oviedo, E., 2007. Effect of moisture content on ammonia emissions from broiler litter: A laboratory study. J. Atmos. Chem. 58, 41-53.

Macklin, K.S., Hess, J.B., Bilgili, S.F. \& Norton, R.A., 2005. Bacterial levels of pine shavings and sand used as poultry litter. J. Appl. Poult. Res. 14, 238-245.

Matković, K., Marušić, D., Pavičić, Ž., Poljičak Milas, N., Ostović, M. \& Lucić, H., 2015. Review of broiler autopodium morphological characteristics as an indicator of accommodation quality and welfare. Proc. 11th Poultry Days 2015, Šibenik, Croatia, pp. 129-132. (in Croatian, English abstract)

Meluzzi, A., Fabbri, C., Folegatti, E. \& Sirri, F., 2008. Survey of chicken rearing conditions in Italy: Effects of litter quality and stocking density on productivity, foot dermatitis and carcass injuries. Br. Poult. Sci. 49, 257-264

Nagaraj, M., Wilson, C.A.P., Hess, J.B. \& Bilgili, S.F., 2007. Effect of high-protein and all-vegetable diets on the incidence and severity of pododermatitis in broiler chickens. J. Appl. Poult. Res.16, 304-312.

Norring, M., Kaukonen, E. \& Valros, A., 2016. The use of perches and platforms by broiler chickens. Appl. Anim. Behav. Sci. 184, 91-96.

Ostović, M., Menčik, S., Ekert Kabalin, A., Gregurić Gračner, G., Vučemilo, M., .., Pavičić, Ž., 2015. The effect of rubber flooring on displaying stereotypies in gilts. Berl. Munch. Tierarztl. Wochenschr. 128, 14-19.

Pettit-Riley, R. \& Estevez, I., 2001. Effects of density on perching behaviour of broiler chickens. Appl. Anim. Behav. Sci. 71, 127-140.

Ramadan, S.G.A., Mahboub, H.D.H., Helal, M.A. \& Gaafar, K.M., 2013. Behaviour, welfare and performance of broiler chicks reared on different litter materials. Assiut Vet. Med. J. 59, 9-18.

Riber, A.B., Van de Weerd, H.A., De Jong, I.C. \& Steenfeldt, S., 2018. Review of environmental enrichment for broiler chickens. Poult. Sci. 97, 378-396. 
Shepherd, E.M. \& Fairchild, B.D., 2010. Footpad dermatitis in poultry. Poult. Sci. 89, 2043-2051.

Simsek, U.G., Dalkilic, B., Ciftci, M., Cerci, I.H. \& Bahsi, M., 2009. Effects of enriched housing design on broiler performance, welfare, chicken meat composition and serum cholesterol. Acta Vet. Brno 78, 67-74.

Swiatkiewicz, S., Arczewska-Włosek, A. \& Jozefiak, D., 2017. The nutrition of poultry as a factor affecting litter quality and foot pad dermatitis - an updated review. J. Anim. Physiol. Anim. Nutr. 101, e14-e20.

Škrbić, Z., Pavlovski, Z., Lukić, M. \& Petričević, V., 2015. Incidence of footpad dermatitis and hock burns in broilers as affected by genotype, lighting program and litter type. Ann. Anim. Sci. 15, 433-445.

Taira, K., Nagai, T., Obi, T. \& Takase, K., 2014. Effect of litter moisture on the development of footpad dermatitis in broiler chickens. J. Vet. Med. Sci. 76, 583-586.

Tasistro, A.S., Ritz, C.W. \& Kissel, D.E, 2007. Ammonia emissions from broiler litter: Response to bedding materials and acidifiers. Br. Poult. Sci. 48, 399-405.

Terčič, D., Žolger, M. \& Pestotnik, M., 2015. Effect of different litter materials on foot pad dermatitis, hock burn and feather coverage in broiler chickens. Acta Agric. Slov. 106, 97-101.

Ventura, B.A., Siewerdt, F. \& Estevez, I., 2012. Access to barrier perches improves behavior repertoire in broilers. PLoS ONE 7(1), e29826.

Vučemilo, M., Matković, K., Vinković, B., Jakšić, S., Granić, K. \& Mas, N., 2007. The effect of animal age on air pollutant concentration in a broiler house. Czech J. Anim. Sci. 52, 170-174.

Vučemilo, M., Matković, K., Vinković, B., Macan, J., Varnai, V.M., Prester, Lj., Granić, K. \& Orct, T., 2008. Effect of microclimate on the airborne dust and endotoxin concentration in a broiler house. Czech J. Anim. Sci. 53, 83-89.

Zhao, Z., Li, J., Li, X. \& Bao, J., 2014. Effects of housing systems on behaviour, performance and welfare of fast-growing broilers. Asian-Australas. J. Anim. Sci. 27, 140-146. 